\title{
Is it a competent child's prerogative to refuse medical treatment?
}

\author{
Mariana Buchner-Eveleigh \\ $L L M, L L D$ \\ Senior lecturer, Department of Private Law, University of Pretoria
}

\begin{abstract}
SUMMARY
The purpose of this article is to analyse the legal position pertaining to the refusal of medical treatment by a competent child as an expression of his or her rights to physical integrity and autonomy guaranteed in the Constitution of the Republic of South Africa, 1996. The article also examines how the Children's Act gives effect to the child's right to refuse medical treatment in order to determine whether it demonstrates respect for a child's rights to bodily integrity and autonomy. Thereafter the question whether the refusal of a competent child should be overridden with specific reference to the child's best interests is addressed.
\end{abstract}

\section{Introduction}

All persons, including children, have the right to bodily integrity (including the ability to make autonomous decisions regarding one's own body) which in the simplest of terms means that a person has the right to decide what happens to his or her body. In a health care context, this right necessitates a right to give or withhold informed consent, ${ }^{1}$ before any procedure is undertaken or another process affecting one's body begins. $^{2}$

For purpose of medical treatment, ${ }^{3}$ children are considered to have the capacity to consent if they comply with two requirements namely (1) age and (2) maturity and understanding. ${ }^{4}$ When children reach the age of 12 and provided they are of sufficient maturity and have the mental capacity to understand the benefits, risks, social and other implications of the medical treatment they are deemed to be competent to consent to

1 With reference to Castell $v$ De Greef 19944 SA 408 (C), Mojapelo J found in Christian Lawyers Association v Minister of Health 20044 All SA 31 (T) that the rationale behind the requirement of informed consent in medical procedures was to give effect to the patient's fundamental right to selfdetermination (autonomy), which is protected by amongst others s 12(2) (the right to bodily and psychological integrity, including the right to security in and control over the body) of the Constitution of the Republic of South Africa, 1996 (hereafter the Constitution).

2 Nienaber \& Bailey "The right to physical integrity and informed refusal: Just how far does a patient's right to refuse medical treatment go?" 2016 SAJBL 74.

3 For the purposes of this article, medical treatment means a non-invasive intervention usually in the form of a drug.

4 Mahery in Boezaart (ed) Child law in South Africa (2017) 263-264.

How to cite: Buchner-Eveleigh 'Is it a competent child's prerogative to refuse medical treatment?' 2019 De Jure Law Journal 242-256

http://dx.doi.org/10.17159/2225-7160/2019/v52a15 
medical treatment. ${ }^{5}$ Requiring children to be mature and to possess the capacity to understand the consequences of the treatment reinforces the application of the common law-doctrine of informed consent, ${ }^{6}$ in all health care settings. ${ }^{7}$

The position of the refusal of medical treatment, including life-saving treatment, by children has not been set out with clarity in the Children's Act. ${ }^{8}$ The existence of the right of children to refuse medical treatment has been inferred from the wording of section 129(2) of the Children's Act. This section, as indicated above, sanctions the right of a child to consent to medical treatment and considering that refusal is the converse of consent, ${ }^{9}$ section 129(2) must surely sanction the right of a child to refuse medical treatment as well. ${ }^{10}$ Therefore, drawing on section $129(2)$ of the Children's Act a child is competent to refuse medical treatment if he or she is 12 years or older and of sufficient maturity to understand the risks and consequences of refusing medical treatment.

If the child is legally competent to refuse medical treatment the refusal to medical treatment, including life-saving treatment should be respected. However the informed refusal of a child can be overridden by the court, ${ }^{11}$ or the minister. ${ }^{12}$ No distinction is made between a competent and an incompetent child in deciding whether or not to override the child's decision to refuse medical treatment. The question posed by this article is whether the refusal by a competent child should be overridden?

The purpose of this article is to analyse the legal position pertaining to the refusal of medical treatment by a competent child as an expression of his or her rights to physical integrity and autonomy guaranteed in the

5 S 129 Children's Act 38 of 2005.

6 At common law the courts have held that for an informed consent to medical treatment the patient must: (i) have knowledge of the nature and extent of the harm or risk involved; (ii) have an appreciation and understanding of the nature of the harm or risk; (iii) have consented to the harm or assumed the risk and have provided a consent that is comprehensive and that extents to the entire transaction, including its consequences. See Castell $v$ De Greef supra and Christian Lawyers Association $v$ Minister of Health supra.

7 Mahery 264

838 of 2005 .

9 Lemmens "End-of-life decisions and minors: Do minors have the right to refuse life preserving medical treatment? A comparative study" 2009 Medicine and Law 479.

10 McQuoid Mason "Can children aged 12 years or more refuse lifesaving treatment without consent or assistance from anyone else?" 2014 SAMJ 467. See also Chetty An examination of the rights of the child to refuse medical treatment: A South African perspective (LLM theses 2016 UKZN) 2; Mahery 272.

11 See s 29(9) of the Children's Act. The High court or children's court can consent where anyone who may consent (that includes a child that complies with s 129(2)) refuses to consent.

12 See s 29(8) of the Children's Act. The minister may consent to medical treatment of a child if the child unreasonably refuses to give consent. 
Constitution of the Republic of South Africa, 1996 (hereafter "the Constitution"). I will also briefly look at how the Children's Act gives effect to the child's right to refuse medical treatment to determine whether it demonstrates respect for a child's rights to bodily integrity and autonomy. Thereafter I will address the question whether the refusal of a competent child should be overridden with specific reference to the child's best interests.

\section{The Constitution}

\section{The rights in the Bill of Rights relating to children}

"Constitutional rights do not mature and come into being magically only when one attains the [S]tate-defined age of majority. Minors, as well as adults, are protected by the Constitution and possess constitutional rights." 13

According to section 7(1) of the Constitution, both adults and children alike are bearers of rights. ${ }^{14}$ Since children are viewed as the most vulnerable members of South Africa's society, section 28 has been included to provide particular protection and rights for children. While the rights in section 28 apply exclusively to children, this does not bar children from the enjoyment, protection and application of other human rights found within the Bill of rights. ${ }^{15}$

Many of the rights which are found in section 28 are, in fact, mere repetition of the rights found in the other sections and can therefore be classed as background rights to the specific rights of children. ${ }^{16}$ An important observation, however, is that while not all rights are repeated in section 28, they nevertheless remain important for children. These rights include the right to equality, ${ }^{17}$ dignity, ${ }^{18}$ bodily and psychological integrity, ${ }^{19}$ and the right to individual autonomy. ${ }^{20}$ It is the last mentioned two rights which are of particular importance to the topic of this article which require detailed discussion.

13 Du Plessis, Van der Walt \& Govindjee "The constitutional rights of children to bodily integrity and autonomy" 2014 Obiter 2.

14 S 7(1) states "This Bill of Rights is a cornerstone of democracy in South Africa. It enshrines the rights of all people in our country and affirms the democratic values of human dignity, equality and freedom."

15 Skelton \& Proudlock in Davel \& Skelton (eds) Commentary on the Children's Act (2007) 1-7; Du Plessis, Van der Walt \& Govindjee 2014 Obiter 2.

16 Kruger "The protection of children's rights in the South African Constitution: reflections on the first decade" 2007 THRHR 241; Du Plessis, Van der Walt \& Govindjee 2014 Obiter 2.

17 S 9 of the Constitution of the Republic of South Africa, 1996 (hereafter "the Constitution").

$18 \mathrm{~S} 10$ of the Constitution.

19 S 12(2) of the Constitution. 


\section{Children's rights to bodily integrity}

As bearers of rights, children have the right to bodily integrity which is found under the protection of so-called "umbrella right" of freedom and security of the person in section 12 of the Constitution. The right to bodily integrity specifically comprises: ${ }^{21}$

"[The right] (a) to make decisions concerning reproduction;

(b) to security in and control over their body; and

(c) not to be subjected to medical or scientific experiments without their informed consent."

The right to bodily integrity amounts essentially to a "right to be left alone", ${ }^{2}$ in other words a right to make decisions concerning one's body without undue interference by others. ${ }^{23}$ Section 12(2)(b) refers to the right to security in and control over the body. The right to security in the body prevents unwanted invasion of bodily integrity by the state and others, as would arise in the situation where a patient is forced to undergo treatment; whereas the right to control over the body amounts to the ability to make autonomous decisions regarding one's own body. $^{24}$ The wording of section 12(2)(b) assumes that individuals are capable of taking decisions that are, at the very least, in their own interests. Linked to this, it is often argued that interference and intervention in the lives of others must, in general, be minimised. This implies that, while a person may experience and express genuine concern for the well-being of another, the choices made by the other person, with respect to issues relating to bodily integrity, must ultimately be respected. 25

In a health care context, the right to bodily integrity protects individuals from being subjected to any form of medical treatment that is against their wishes, and from any imposition of treatment that is a product of a third party's perception of being in the best interests of the

20 Despite not being found within a particular section of the Constitution it is arguable that the right is constructed from the rights to freedom and security, to privacy, to dignity, freedom of religion, freedom of expression and freedom of association read together. See Bekink \& Brand in Davel (ed) Introduction to child law in South Africa (2000) 169-178; Kruger 2007 THRHR 241; Kruger "Traces of Gillick in South African jurisprudence: Two variations on a theme" 2005 Codicillus 11; Du Plessis, Van der Walt \& Govindjee 2014 Obiter 3, 5.

$21 \mathrm{~S} 12(2)$ of the Constitution.

22 Nienaber \& Bailey 2016 SAJBL 74; Currie \& De Waal The Bill of Rights Handbook (2005) 287.

23 Nienaber \& Bailey 2016 SAJBL 74.

24 Nienaber \& Bailey 2016 SAJBL 74; Currie \& De Waal 287.

25 Du Plessis, Van der Walt \& Govindjee 2014 Obiter 4; Bishop \& Woolman in Woolman \& Bishop (eds) Constitutional law of South Africa (2008) 40-85. As Sachs and O'Regan JJ noted in Sv Jordaan 20026 SA 642 (CC), [the body is not] something to be commodified. Our Constitution requires that it be respected." (par 74). 
patient concerned. ${ }^{26}$ This right necessitates a right to give or withhold informed consent before any procedure is undertaken or another process affecting one's body begins. ${ }^{27}$ Patients, who wish to refuse medical treatment, including life-saving treatment, are free to make this decision. In doing so, they are deciding what happens to their own bodies. These patients are merely exercising their right to refuse medical treatment as permitted by the right to bodily integrity. ${ }^{28}$

\section{Children's right to autonomy}

The quintessence of the right to bodily integrity is the contentious right to autonomy or self-determination. ${ }^{29}$ This refers to the right that a person has to decide what they want to be done with their body, without anybody else deciding such matters for them. ${ }^{30}$

Support for a child's right to autonomy can be found in the work of several authors. Freeman, for example proposes four categories of rights for children, of which the third and fourth categories respectively validate a child's right to autonomy. The right to be treated as an adult is the third of Freeman's categories and proposes that the rights and liberties afforded to adults should also be extended to children. ${ }^{31}$ Based on the research of developmental psychologists, Freeman argues that the agerelated restrictions placed on children should be constantly reviewed, alternatively that the legal capacity of children to make decisions should be determined on a case-by case basis, given that maturity levels differ amongst children, irrespective of their age. ${ }^{32}$ Freeman's fourth category of children's rights is rights against parents. It is this component of the right, which would, for example, allow for claims of independence from parental control before the age of majority is attained. ${ }^{33}$ These rights against parents would also, for example sanction a child's decisionmaking powers in matters such as consent to medical treatment and termination of pregnancy. Findings of research done by developmental psychologists regarding the intellectual, social and moral development of children also indicate that a child reaches adult decision-making

26 Biggs Euthanasia, Death with Dignity and the Law (2001) 95.

27 Nienaber \& Bailey 2016 SAJBL 74; Carstens \& Pearmain Foundational principles of South African medical law (2007) 30.

28 This right is supplemented in the National Health act, particularly in s 6 dealing with informed refusal. A discussion of s 6(d) follows in paragraph 3 hereunder.

29 Despite not being found within a particular section of the Constitution it is arguable that the right to autonomy is constructed from the rights to freedom and security, to privacy, to dignity, freedom of religion, freedom of expression and freedom of association read together. Furthermore in $N M v$ Smith 20075 SA 250 (CC) par 145-146 O'Regan J suggested autonomy as a constitutional value that underlies human dignity, freedom and privacy. See Du Plessis, Van der Walt \& Govindjee 2014 Obiter 3, 5.

30 Du Plessis, Van der Walt \& Govindjee 2014 Obiter 5.

31 See Du Plessis, Van der Walt \& Govindjee 2014 Obiter 5; Freeman The rights and wrongs of children (1983) 22-23.

32 See Du Plessis, Van der Walt \& Govindjee 2014 Obiter 5; Freeman 46.

33 See Du Plessis, Van der Walt \& Govindjee 2014 Obiter 5; Freeman 48. 
capacities around mid-adolescence. ${ }^{34}$ It is clear that the right to autonomy ensures that children enjoy a level of independence from their parent.

Autonomy has also been recognised as a constitutional value that underlies freedom, human dignity and privacy. ${ }^{35}$ As a constitutional value, it has been defined by the courts as "the ability to regulate one's own affairs, even to one's own detriment". 36 Implicit in this juridical definition is the acknowledgement of autonomy as a developmental phenomenon. This is inferred by the term "ability" implying that autonomy is an evolving capacity that is, acquired in the process of human development. According to the provisions of the United Nations Convention on the Rights of a Child, 1989 (hereafter "UNCRC") and the African Charter on the Rights and Welfare of the Child, 1990, (hereafter "ACRWC") a child has autonomy rights. ${ }^{37}$ The Children's Act first defines a child as a person below the age of 18 years and further specifies in section 129 which children can fully exercise autonomy rights in the setting of consent to medical treatment.

As the right to bodily integrity including the ability to make autonomous decisions regarding one's own body is enshrined in the Constitution medical practitioners have a general legal obligation to respect this right of patients. It is submitted that children should be authorized to refuse medical treatment and to enforce this decision especially in terms of the right to bodily integrity. This submission has been made for two reasons. The first reason is that children are equally entitled to the right to bodily integrity. It is therefore submitted that they may exercise this right to effectively refuse medical treatment if they are competent to exercise the autonomy that they have been automatically afforded by the right to bodily integrity. The second reason is that in order to give effect to the right to bodily integrity, it is obvious that children must be competent to make autonomous decisions and once competence has been confirmed, the refusal must be respected and enforced regardless of the consequences. ${ }^{38}$

34 Kruger 2005 Codicillus 6; Buchner-Eveleigh "Section 71 of the National Health Act: Call for review of the consent requirement to child participation in health research" 2015 De Jure 284. See also Zuch (et al) 2012 BMC International Health and Human Rights 4; Freeman "Taking children's rights more seriously" 1992 International Journal of Law and the Family 59, 67.

35 See NM V Smith 20075 SA 250 (CC) par 145-146.

36 Jordaan "Autonomy as an element of human dignity in South African case law" 2009 Journal Philosophy, Science and Law 6.

37 Ganya, Kling \& Moodley "Autonomy of the child in the South African context: Is a 12 year old of sufficient maturity to consent to medical treatment" 2016 BMC Medical Ethics 17: 66. Also available at https:// doi.org/10.1186/s12910-016-0150-0.

38 Hill "Constituting children's bodily integrity" 2014 Duke Law Journal 1297; Chetty 47 . 


\section{Children's Act}

The promulgation of the Children's Act sought to supplement and give effect to the rights that children already enjoy in terms of the Constitution. 39 The provisions of the Children's Act aim further to provide children with the care, protection and safeguards that will ensure that their constitutional rights are being fulfilled, while their overall wellbeing is being promoted and strived for concurrently. ${ }^{40}$ The Act governs a wide range of interests and rights that children are entitled to. Section 129 of the Act specifies which children can fully exercise autonomy rights in the setting of consent to medical treatment.

Section 129 provides that a child over the age of 12 years who is of sufficient maturity and who has the mental capacity to understand the benefits, risks and social and other implications of the treatment may consent to medical treatment on their own. Two requirements must be complied with before a child can consent on his or her own. These two requirements determine a child's competency for purpose of consenting to medical treatment. These requirements are (1) age, ${ }^{41}$ and (2) maturity and understanding. The position of the refusal of medical treatment by children has not been set out with clarity in the Act. The existence of the right of children to refuse medical treatment has been inferred by section $129(2)$ of the Children's Act. This section, as stated above, ${ }^{42}$ sanctions the right of a child to consent to medical treatment and considering that refusal is the converse of consent, section 129 (2) of the Children's Act must surely sanction the right of a child to refuse medical treatment as well. Therefore, drawing on section 129(2) of the Children's Act, a child is competent to refuse medical treatment if he or she fulfils the age (12 years or older) and maturity and understanding requirements.

The second requirement namely maturity and understanding requires further discussion. Maturity is the ability to comprehend, understand and assess the implications of a particular matter. ${ }^{43}$ More importantly, maturity is the ability to understand the nature of medical treatment, the consequences (emotional, psychological etc.) and associated risks that follow of consenting (or not) to it. Therefore a determination of competence also depends on the abilities of a child. ${ }^{44}$ In order to satisfy the medical professional or court, as the case may be, the child must demonstrate his or her ability to understand. Although there is no provision in the Act specifying how the child's ability ought to be

39 The aims of the Children's Act are set out in the long title.

40 Du Plessis, Van der Walt \& Govindjee 214 Obiter 7.

41 The age is 12 years. The legislature elected to adopt a fixed age approach possibly in the interests of greater legal certainty for those involved in providing medical treatment in all its forms. See Sloth-Nielson in Davel \& Skelton (eds) Commentary on the Children's Act (2007) 7-31.

42 Par 1.

43 Committee on the Rights of the Child, General Comment 12, para 30.

44 Trowse 'Refusal of Medical Treatment - A Child's Prerogative?' 2010 Queensland University of technology Law and Justice Journal (QUTLJJ) 207. 
assessed questions will be asked and discussions held with the child in order to establish whether or not the child's level of understanding is sufficient. An ability to understand the treatment alone is insufficient. The child must be able to understand the consequences and associated risks of accepting the treatment and the dangers of not accepting treatment. ${ }^{45}$ This extends beyond an ability to understand physical aspects of the treatment. It extends to other related circumstances surrounding the treatment. An ability to understand social, emotional and psychological issues must be demonstrated. ${ }^{46}$ It follows that treatment of a more complicated nature would involve a series of highly comprehensive discussions, almost to the point of interrogation, in order to establish whether or not the child can satisfy the second requirement of competence. ${ }^{47}$ In order to understand the child's ability to understand, it is likely that, in the course of these extensive discussions, the child actually becomes highly apprised of the treatment, its effects on the child and on others. Through this physical process, the child's ability to understand becomes an actual understanding - how else can ability be measured? ${ }^{48}$

Requiring the child to be sufficiently mature and to possess the capacity to understand the nature, consequences and risks of the treatment reinforces the application of the common law doctrine of informed consent in all health care settings. This doctrine rests on 3 legs namely knowledge, ${ }^{49}$ appreciation, ${ }^{50}$ and consent. ${ }^{51}$ Where a child decides to give or withhold informed consent knowledge and understanding in a child must be proved and therefore demonstrated by the child. Discourse must occur to prove competence and this will involve discussions, questions and answers. If the treatment is serious, the discussions are likely to be rigorous and onerous. ${ }^{52}$ To avoid the ramifications of a wrong decision it is obvious that the person making the determination of competency will ensure that the child is well informed and knowledgeable and therefore very capable of making a decision.

Once competence has been established, it is submitted that it affords the child the decision-making competence of an adult. If it does not afford adult competence on a child, it raises the implication that there are two levels of competence - "adult competence" and "child competence" - the latter being a lesser level/form of competence and one can then ask

45 Trowse 2010 QUTLJJ 206.

46 Trowse 2010 QUTLJJ 206

47 Trowse 2010 QUTLJ 207.

48 Trowse 2010 QUTLJJ 207.

49 Knowledge means that the patient who consents must have full knowledge of the nature and extent of the harm or risk involved.

50 Appreciation implies that the person must understand or comprehend the nature and extent of the harm or risk.

51 Consent means that the patient must in fact subjectively consent to the harm or risk, and his or her consent must be comprehensive, in that it must extend to the "entire transaction', including its consequences. See Mahery 264.

52 Trowse 2010 QUTLJJ 211. 
whether there would be any need to assess the competence of a child at all. ${ }^{53}$ Thus once competence has been established the child's refusal should be respected, regardless of the consequences. The child can thus exercise his or her right to bodily integrity (including autonomy) by refusing medical treatment just as an adult.

However, the Act states that the best interests of the child are of paramount importance in every matter concerning the child. Satisfying the requirements of age and maturity and understanding appear not to suffice, although a legal requirement, ${ }^{54}$ as a decision made by a child who does satisfy these principles may be overridden by the court if it is found that the proposed medical treatment is in the child's best interests. $^{55}$ The refusal may also be overridden by the Minister of Home Affairs if the child unreasonably refuses medical treatment. ${ }^{56}$ When deciding the reasonableness or otherwise of the child's refusal, the minister should judge it against the best interests of the child standard. ${ }^{57}$ If the court or the minister is of the opinion that it is in the best interest of the competent child to override his or her refusal the competent child is then compelled/forced to undergo medical treatment.

- The question that arises is whether it is in the best interest of a competent child to override his or her refusal to medical treatment, in particular life-saving treatment. No South African court has pronounced on this difficult issue yet. In order to develop South African law it is also necessary to critically look at foreign cases which have ruled on the refusal of treatment. ${ }^{58}$

\section{Is it in the best interests of a competent child to override his or her informed refusal to medical treatment, including life-saving treatment?}

South Africa holds the best interests of children in high esteem and the seriousness with which it regards such interests are reflected in various statutory provisions. ${ }^{59}$ The Constitution makes it a vital right for all children and a responsibility to be fulfilled that "a child's best interests are of paramount importance in every matter concerning the child'.60

53 Trowse 2010 QUTLJJ 204.

54 Lemmens 2009 Medicine and Law 493.

55 S 129(9).

56 S 129(8).

57 McQuoid Mason 2014 SAMJ 468; Mahery Children's health service rights and the issue of consent (LLM dissertation 2007 UWC) 73.

58 S 39 of the Constitution stipulates that foreign law must be considered in order to develop South African law regarding a child's refusal of medical.

59 Moyo "Reconceptualising the 'paramountcy principle": Beyond the individualistic construction of the best interests of the child" 2012 AHRLJ 143.

60 S 28(2) of the Constitution. 
This provision has influenced the drafters of the Children's Act to include the paramountcy of these interests in the Act. Therefore, section 9 of the Children's Act was drafted to confirm that the best interests of the child shall be the primary consideration in all actions concerning the child undertaken by any person or authority. This section has been supplemented by section 7 of the Children's Act which lists several factors that must be considered when determining what would be in the best interests of children. Of particular applicability to medical treatment are the consideration of the child's age, maturity, and stage of development, ${ }^{61}$ and the child's emotional and physical security and his or her emotional, intellectual, cultural and social development, together with any disability or chronic illness from which the child may suffer. ${ }^{62}$ Another factor that is of possible relevance to the consideration of what would be in the best interests of the child with regard to medical treatment, is the protection of children from any psychological or physical harm that may arise from subjecting the child to degradation or harmful behaviour. ${ }^{63}$

International and regional human rights conventions such as the UCRC and the ACRWC are comprehensive instruments, which further confirm the importance of promoting the best interests of children. The UCRC orders that: ${ }^{64}$

"In all actions concerning children, whether undertaken by public or private social welfare institutions, courts of law, administrative authorities or legislative bodies, the best interests of the child shall be a primary consideration."'

These provisions are reaffirmed by the ACRWC, which stipulates that the standard of the best interest of the child be of paramount importance, and must be applied in all actions concerning the care, protection and well-being of a child. ${ }^{65}$

The above provisions guarantee that the best interests of the child will be given due consideration and will be the basis upon which all matters concerning the child will be decided. However, what is in the best interests of a competent child with regard to refusal of medical treatment remains unclear. Decisions which claim to be made in the best interests of children, such as overriding refusals of medical treatment by competent children, do not reflect the wishes of competent children and they are therefore forced to undergo medical treatment. ${ }^{66}$ To override the refusal by a competent child is to allow a third party's view to

$61 \mathrm{~S} 7(1)(\mathrm{g})(\mathrm{i})$.

62 S 7(1)(h)-(j)

63 S 7(1)(1).

64 Art 4(1).

65 Art 3(1).

66 Moyo 2012 AHRLJ 144. Parents believe that it is in the best interests of their children to receive medical treatment; while children who refuse medical treatment clearly hold the view that it is in their best interests not to undergo the medical treatment. 
determine the child's best interest rather than the competent individual whose health is at stake.

Satisfying the requirements of age and maturity and understanding appear not to suffice, although a legal requirement, as a decision made by a child who does satisfy these requirements can be overridden if the court is of the opinion that the treatment is in the best interests of the child. ${ }^{67}$ It seems as if the lengthy assessment of competence becomes a meaningless exercise to the point where competence merely becomes one among many factors that the court considers when determining what would be in the best interests of the child. ${ }^{68}$ It is submitted that this is an incorrect application of the law as competence is the ground upon which children are judged in order to determine whether they are capable of making autonomous decisions concerning their health. ${ }^{69}$ Once competence has been established, it should not be marginalized as if it holds no value for the sake of an objective notion held by courts of what is in the best interests of the child. This has, unfortunately, been the common occurrence in several English cases where the courts stated that it could override the refusals to medical treatment by competent children where it is in their best interests to do so. These cases illustrate the courts' reluctance to regard the decisions to refuse medical treatment by competent children as determinative in cases where the refusal would result in the death or severe permanent injury to the children. ${ }^{70}$ In $R e W$ (A Minor), ${ }^{71}$ the Court of Appeal overrode a competent child's refusal to medical treatment because it would have resulted in the child's death. The court conceded that it couldn't lightly override the decisions made by a competent child with respect to medical treatment; however, the court had followed this statement by adding that it could do so if it were in the best interests of the child. Lord Donaldson noted it would generally be in the child's best interests to follow his or her wishes, except in circumstances where the child refuses medical treatment in circumstances, which would probably result in death or severe permanent injury to the child. 72

The case of Re M (Child: Refusal of Medical Treatment), ${ }^{73}$ differs from the case of $R e W$ in that the child concerned was found not to be competent; however, the court stated that the outcome of this case would

67 Trowse 2010 QUTLJJ 192.

68 Elliston in McLean (ed) Contemporary Issues in Law, Medicine and Ethics (1996) 39.

69 This submission is supported by Canadian cases where the consensus is that children can consent or refuse medical treatment if they are mature and understand the nature of the treatment and the consequences of not receiving that treatment. See Burden-Osmond 2002 Defence Counsel Journal. Available at http://www.allbusiness.com/legal/contracts-agreements /1067823-1.html (assessed 2017-03-12); Mahery 74.

70 Trowse 2010 QUTLJJ 199.

$71 \quad 19924$ All ER 627. This case is the only case where the court actually overrode the decision of a child found by the court to be competent.

72 At 643

73200052 BMLR 124. 
have been the same had the child been found to be competent as it had the power to override the decision of a child, whether or not the child was competent. ${ }^{74}$ The court reasoned that the welfare of the child was the paramount consideration and if the decision made by the child negatively impacted this welfare, the court was obliged to intervene. The court placed emphasis on decisions, which result in the death of the child and stated that "whatever the risk may be in overriding the child's decision, it has to be matched against ... the certainty of death [if she did not receive the treatment]". 75

In the case of $R e W$, the court made a finding of competence and nonetheless, had overruled the decision made by a competent child. It is however important to note that although the child was found to be competent, it was noted by Lord Donaldson that one of the symptoms of the illness is a desire by the sufferer to be in control and refusal of treatment is an obvious way of demonstrating this. ${ }^{76}$ Whilst the finding of competence was not overridden, these words place some doubt on W's ability to honestly evaluate her situation. It is clear that her refusal of treatment could have been based on something other than an ability to understand fully the proposed treatment. ${ }^{77}$ In the case of $\operatorname{Re} M$ the court had found that the child was not competent and accordingly, overruled the decision. It is submitted, that courts should only override decisions by children who do not exhibit complete competence as it is in their best interests to disallow a decision that is made by children who do not have the competence to make such decision. Such children must be protected from making incompetent decisions.

The court in $\operatorname{Re} W$ conceded that it is in the child's best interest to abide by the decision of the child unless there is a danger to the child's health or survival, in which case best interests point to survival. ${ }^{78}$ This is irrespective of whether the child is competent or not. The issue of best interests raises two important questions in the context of a competent child. The first issue is whether a competent child should lose the right to determine what is in his or her best interests because the decision the child makes may risk loss of life or permanent injury. It is important to remember that these decisions are of very personal nature. Medical choices would vary from person to person and views in some cases are likely to be adamant. It appears as if a competent child loses this choice by virtue of being under the age of majority. Court decisions, with similar set of facts, may also not be uniform because there is no right or wrong answer to which form of treatment is in the child's best interests. The subjective views of the decision maker may prevail. ${ }^{79}$ Physical aspects alone further not necessarily judge best interests. Emotional and

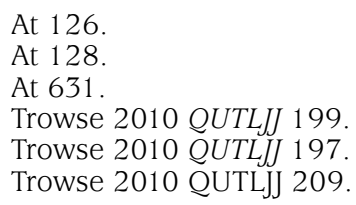


psychological ramifications felt only by the child must be considered and should be respected. ${ }^{80}$

In certain circumstances, the child's best interests are a fine line, which no one except the child requiring the treatment can really understand. Only the competent patient really knows and understands what is in his or her best interests. Only the competent patient should consent or refuse treatment. A competent child is a competent patient, even if he or she is not an adult. The competent child knows his or her best interests and may have very good reasons for acting outside that which a third party considers his or her best interests. ${ }^{81}$

It has been held in Canada, ${ }^{82}$ that the best interests of a competent child were best served by abiding by the child's decision to only accept treatment, which did not require blood transfusion. This was despite medical evidence that the child's refusal to accept blood could be fatal. The court found overwhelming evidence that the child was sufficient mature.

The second issue is whether a competent child should be able to make a decision with respect to medical treatment, which is not in his or her best interests. In other words, if a competent child's decision appears irrational or unreasonable to the objective observers, should the decision be respected as it would be if made by an adult. What is seen as irrational to one person may be common sense to another. Once a person attains the age of majority and legally enjoys adult status, competence is presumed and if not rebutted, decisions made by such individuals are respected. The courts will uphold the decisions of adults (if threats to public health etc. have been ruled out), ${ }^{83}$ irrespective of the detrimental or fatal consequences which follow a refusal of medical treatment. ${ }^{84}$ This has been endorsed in $\operatorname{Re} T$ (adult: refusal of medical treatment), ${ }^{85}$ where Lord Donaldson had recognised that every adult has the prima facie right and capacity to decide whether to accept or refuse medical treatment, regardless of whether the latter may risk permanent injury to health or result in premature death. He further acknowledged that issues surrounding whether or not the reasons for the refusal were rational, irrational, unknown or possibly non-existent were redundant.

If it is accepted that once competence of a child has been established it affords the child the same decision-making competence of an adult (as there is only one level of competence) then the decision of a competent

80 Trowse 2010 QUTLJJ 211.

81 Trowse 2010 QUTLJJ 209.

82 Region 2 Hospital Corp $v$ Walker 1994 NBR 2) LEXIS 1127. See also Trowse 2010 QUTLJJ 209.

83 See Nienaber \& Bailey 2016 SAJBL 74-77.

84 Elliston 41.

8519924 All ER 649. 
child must be respected even if the decision carries with it the risk of death or serious damage to health. ${ }^{86}$ To some (or all) it may appear irrational. However, competence prevails over best interests. Irrational decisions, while heavily scrutinised in terms of competence (like an adult) should be respected. ${ }^{87}$ It is for this reason that section 129(8) of the Children's Act which confers power on the Minister to consent to the medical treatment that has been unreasonably refused by children cannot stand as far as it applies to competent children.

The best interests of the patient are not measured with the purpose of preserving the health and the life of the patient at all costs. ${ }^{88}$ This position is supported by our law in terms of section $6(d)$ of the National Health Act, ${ }^{89}$ which permits competent individuals to refuse health services. The application of this section does not extend to competent adults alone, but to competent children as well. ${ }^{90}$ A child will be able to refuse medical treatment and have such refusal respected provided that the implications, risks and obligations of the refusal of medical treatment have been explained to the child and in return, have been understood and accepted by them. ${ }^{91}$ In addition the child must meet the requirements of age and maturity and understanding.

The best interests of competent children are best served by allowing them to exercise their autonomy by making informed decisions, such as refusal to medical treatment. It is irrational and arbitrary that the competent refusals of adults are respected and upheld, but the competent refusals of children are not. After all, they both have one quality in common and that is competence which ultimately distinguishes between individuals who may make autonomous decisions and those who may not due to their lack of competence. To overrule the refusal of a competent child and compel him or her to undergo medical treatment will violate his or her right to be treated in accordance with his or her best interests and would likewise violate his or her constitutional rights to bodily integrity and autonomy.

\section{Conclusion}

The right to bodily integrity and autonomy is pivotal in any health related context and should not be lightly disregarded. The right of children to possess and fulfil their rights on the same platform as adults is implied by section 7 (1) of the Constitution. ${ }^{92}$ In a health care context this means that a child's refusal to medical treatment should be respected and not

86 See also Trowse 2010 QUTLJJ 210.

87 Trowse 2010 QUTLJJ 210.

88 Elliston 41.

8961 of 2003.

90 Mahery 272.

91 McQuoid Mason "The National Health Act and refusal of consent to health services by children" 2006 SAMJ 531.

92 Chetty 87. 
overridden provided that they are competent. Competent children are well informed and, potentially have a better understanding of the proposed treatment than an adult in the same position. It is submitted that if a child has capacity to refuse medical treatment, he should be treated as an adult, and the decisions respected because it is made by the child in the child's interests. It may not be the best interests from the perspective of the objective bystander, but, if the child is competent, who has the right or ability to query what is in that child's best interests?

Furthermore, if a decision is irrational it should be respected provided competence is found. With competence comes the right to autonomy. There is one level of competence, and if it is achieved, whether by a child or an adult autonomy prevails, regardless of whether the decision is, objectively, in that person's best interests. 